\title{
Local Wisdom in Yogyakarta International Airport
}

\author{
Febriansyah Ignas Pradana \\ College of Aerospace Technology; Parangtritis Street, Druwo, \\ Bangunharjo, Sewon District, Bantul, Special Region of Yogyakarta - 55187 \\ E-mail: ignaspradana@gmail.com
}

\begin{abstract}
The mega construction of Yogyakarta International Airport aims to increase global interaction in Yogyakarta. The existence of an airport in a region should be important. Furthermore, the airport is also able to show the identity of a region itself. The airport can also be a landmark, which is able to represent the cultural values of people in a region. The Special Region of Yogyakarta, which is broadly known as a cultural and educational province, has thousand of cultural values in its local wisdom. This research aims to describe (1) the local wisdom contained in Yogyakarta International Airport, and (2) the values of that local wisdom. Earlier, we have identified the condition of Yogyakarta International Airport, in order to create a research plan for this research. However, we found the main data, namely local wisdom in the airport's building. From that fact, we formed research questions and set the main theory to classify and analyze them. We collect the data under the method of Simak Catat. According to the data, we set Haryanto (2014) theory as the main theory. In order to collect valid and reliable data, we also conduct a deep interview with Andika as an interviewee from PT. Angkasa Pura I is the coordinator of Yogyakarta International Airport. The results show that there are eighteen local pearls of wisdom in Yogyakarta International Airport, and the values of that local wisdom are triggered by the sociocultural aspect.
\end{abstract}

Keywords: local wisdom, airport, yogyakarta international airport

\section{Kearifan Lokal di Yogyakarta International Airport \\ Abstrak}

Pembangunan Bandar Udara Yogyakarta International Airport bertujuan untuk meningkatkan hubungan global yang selama ini telah dilaksanakan di Yogyakarta. Keberadaan dari sebuah bandar udara Internasional di Yogyakarta menjadi sangat vital. Bandar udara selain sebagai pusat dalam kegiatan penerbangan, turut menjadi identitas dari suatu daerah tempat bandar udara tersebut berada. Bandar udara dapat menjadi landmark bagi wilayah karena merepresentasikan kehidupan dan nilainilai budaya yang terkandung di dalam masyarakat. Daerah Istimewa Yogyakarta, yang juga dijuluki kota budaya, memiliki beragam kearifan lokal yang mampu menunjukkan identitas budaya pada sebuah bandar udara. Penelitian ini bertujuan untuk mendeskripsikan (1) kearifan lokal yang terdapat di bandar udara Yogyakarta International Airport, dan (2) nilai-nilai yang terkandung dalam kearifan lokal tersebut. Data utama dalam penelitian ini adalah kearifan lokal yang terdapat pada bandar udara Yogyakarta International Airport. Metode pengumpulan data dalam penelitian ini adalah teknik simak catat. Pada proses analisis data yang turut mencakup proses pengklasifikasian data, selanjutnya data iklasifikasikan berdasarkan teori Haryanto (2014) yang membagi kearifan lokal dalam bentukbentuk atau kategori tertentu. Selanjutnya, data dianalisis secara deskriptif dengan pendekatan mixed-method yaitu pendekatan yang menggabungkan pendekatan kualitatif dan kuantitatif dalam satu waktu. Dari hasil penelitian ini diharapkan menjadi titik awal bagi terciptanya sarana dan prasarana yang tepat guna di sebuah bandar udara Internasional.

Kata kunci: kearifan lokal, bandar udara, bandar udara internasional yogyakarta 


\section{INTRODUCTION}

The construction of Yogyakarta International Airport, which is in this research, referred to as YIA, aims to improve global relations that have been implemented in Yogyakarta (Cornock, 2018). The limited amount of capacity, limited export and import transportation activities and the location in the middle of the settlements owned by Adi Sutjipto International Airport also became the background for the construction of Yogyakarta International Airport (Cornock, 2018).

According to the Central Statistics Agency of the Special Region of Yogyakarta in January 2019, Adi Sutjipto Yogyakarta airport has 267,237 arriving passengers for domestic arrivals and 17,186 passengers for international arrivals. The number of passengers departing from Adi Sutjipto airport also showed relatively high results, namely 311,299 passengers (Yogyakarta Province Central Bureau of Statistics. 2019. In https://yogyakarta.bps.go.id, August 17, 2019). Based on these statistical data, it can be concluded that the number of passengers at Adi Sutjipto airport has exceeded the specified capacity, which is $1,200,000$ passengers per year (Timbul, 2016).

These results also show that activity level at Yogyakarta airport is relatively high and makes the existence of an international airport in Yogyakarta very vital. Apart from being the center of aviation activities, an airport also becomes the identity of an area where the airport is located. An airport can be a landmark for the region because it represents society's life and cultural values. The Special Region of Yogyakarta, also known as the city of culture, has a variety of local wisdom that can show a cultural identity at an airport. According to Istiawati (2016), local wisdom is a conceptual idea that lives in society, grows, and develops continuously in people's consciousness, from sacred life to profane ones (daily life and its ordinary nature only). Local wisdom can be understood as local ideas that are wise, full of wisdom, good value, embedded and followed by community members.

Based on the theory put forward by Haryanto (2014), forms of local wisdom can be in the form of language, culture, values, norms, ethics, beliefs, customs, customary law, and special rules. In addition to values and habits, local wisdom can also take the form of tangible objects, one example of which is wayang (Sutarso \& Murtiyoso, 2008). Local wisdom that is shown in certain forms contains cultural values that carry specific messages. Based on the initial review conducted by researchers on August 16, 2019, local wisdom was found in the form of kawung batik motifs on the departure information board, as shown in Figure 1 below. 


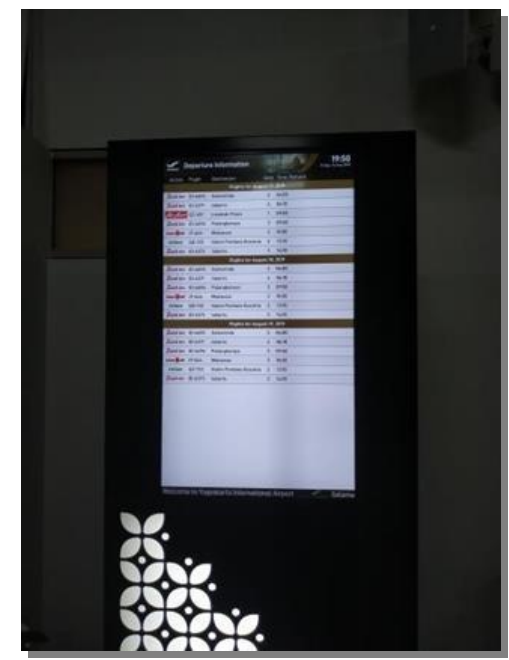

Figure 1. Batik Kawung Motif on the Departure Information Board Source: Author Documentation, 2020

The Kawung Batik that is used as a motif on a notice board contains a thick cultural value. Steelyana (2012) explains that the kawung motif describes the ideal order of community life. This kawung motif contains a message to become a human being who is superior, good, and beneficial to fellow humans. Different from Binsar Siahaan, which have conducted a research in 2017 in a paper entitled "International Airport Terminal in Yogyakarta with a Green Architecture Approach" Based on this background, also I. S. Purwanto in 2017, which describes local wisdom contained in literary works, this study aims to describe (1) the local wisdom found in Yogyakarta International Airport and (2) the values contained in those local wisdom.

\section{MATERIALS AND METHOD}

The research method is essentially a scientific way to obtain data with specific purposes and uses (Williamson et al., 2018). This statement is reinforced by Sugiyono (2015) statement, which states that the research method is a branch of science that discusses or questions ways to carry out research, including activities to search, record, formulate, analyze, to compile reports based on facts or symptoms scientifically. The initial stage in the research carried out by the chief researcher was identifying the conditions of the research location, namely YIA airport. Furthermore, from the review results, the chairman and members of the researcher succeeded in formulating the problems and objectives of the research. There are primary data used in this study. This data is local wisdom found at Yogyakarta International Airport. Data in the form of local wisdom in physical or non-physical form. Physical local wisdom can be in puppets to local batik motifs found in all parts of the airport. 
In contrast, non-physical local wisdom can translate announcements using regional languages in oral announcements at airports. The chairperson and members of the researcher collected data using the note-taking technique (Suter, 2014), where the researcher saw actual events in the field and then recorded them on a data card. It is understood as a note-taking technique because, in this technique, the researcher observes the data source carefully, directed, and thoroughly. This is done in an effort for researchers to obtain the desired data. The results obtained from the observation are then recorded as data (Williamson et al., 2018).

After the data has been successfully collected from the data source, the researcher's next step is to analyze the data. In the data analysis process also includes the data classification process. Data is classified based on Haryanto's (2014) theory, which divides local wisdom into certain forms or categories. Furthermore, the data were analyzed descriptively with a mixed-method approach, namely an approach that combines approaches qualitative and quantitative at one time (Palinkas et al., 2015). A qualitative approach to explaining in-depth local wisdom in YIA airport and a quantitative approach to state the local wisdom found at YIA airport.

The next step carried out by the head researcher to answer the second problem formulation was an interview conducted with Angkasa Pura I as the official manager of Yogyakarta International Airport. The interview technique is a method for collecting and analyzing data (Sugiyono, 2015). The use of interviews in this study is included in interviews as a method to test, namely interviews are used to test the truth and stability of a dictum that has been obtained in other ways. From the results of these interviews, data were obtained that successfully solidified the researcher's assumptions. After the data was analyzed successfully, the researcher validated the data analyzed with the cultural and tourism office of the Yogyakarta Special Province.

The presentation of the results of the analysis in this study used formal and informal methods. The informal method is presented in sentences and paragraphs, while the formal method uses tables (Creswell \& Plano-Clark, 2011). The form of sentences and paragraphs in this study describes qualitatively the local wisdom found at YIA airport and local wisdom value. Formally, it means that the data is contained in tables and diagrams that contain the entire corpus of data used in this study (Sugiyono, 2015). After the study results are presented, the chairman and members of the researcher draw up conclusions from the study. As an outcome, the lead researcher presented the research carried out at the International Seminar and published the research in an accredited international journal. In summary, this research is illustrated in the flow chart and table of the following performance indicators. 


\section{RESULTS AND DISCUSSIONS}

\section{A. Main Concept of Artwork: Jogja Renaissance}

Renaissance, or in Indonesian called Renaisans is the rebirth of a new civilization created from the acculturation of traditional culture with modern culture. Yogyakarta has strong cultural values and is firmly held by its citizens. This culture then moves in a more dynamic direction, mixing with modern culture without losing its original cultural identity. Yogyakarta Renaissance is a continuous process of rebirth without destroying cultural roots. Furthermore, the Renaissance was a cultural revolution against the rigidity of thought and tradition. The concept of rationalism was chosen to give birth to the Jogja Gumregah movement to break away from the confines of mythology and dogmatic stagnation through the process of the Gumregah of culture to a superior cultural level. In the past, superior civilization has shown evidence of upholding the noble values, virtues, and identity of Yogyakarta.

Earth was created to give life to all of His servants, with various cultures produced as forms of life. This process continues and grows until the end of time by producing a new civilization as a form of perfection of the previous civilization, without eliminating the divine cultural identity, namely a civilization with one Godhead. This can be realized if we can control our passions to achieve a balance between spiritual and rational in the process of creating this culture. These concepts are contained in the following local wisdom.

\section{1) Joglo Semar Tinandu}

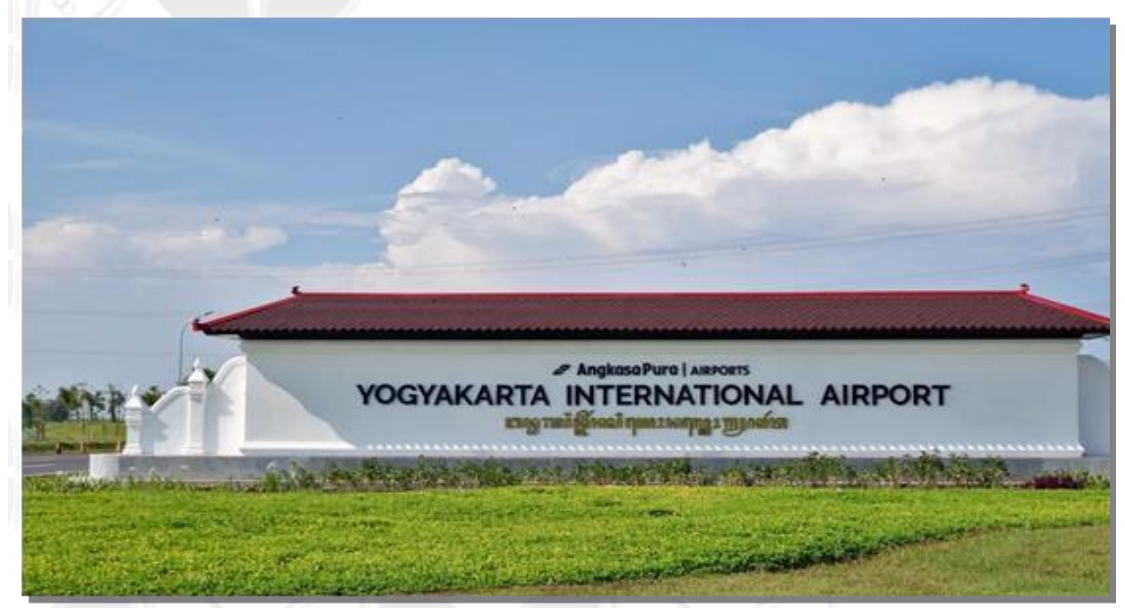

Figure 2. Joglo Semar Trinandu in Yogyakarta International Airport Source: Researcher's documentation 
YIA's Joglo Semar Tinandu building was inspired by the gate of the Ngayogyakarta Hadiningrat Palace called Joglo Semar Tinandu (Semar Diusung/Semar Dipikul). In the Semar Tinandu concept at the gate or YIA 'regol', there is also a combination of Kulon Progo's typical geblek ornament. This combination makes the local cultural characteristics of Kulon Progo, Yogyakarta, and Kraton Ngayogyakarta feel intact for passengers and potential passengers.

\section{2) Welcome Statue "Hamemayu Hayuningrat"}

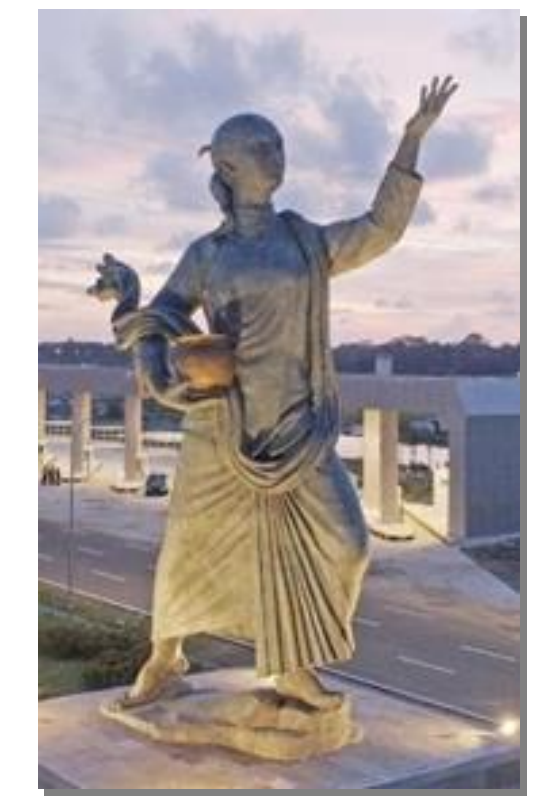

Figure 3. Hamemayu Hayuningrat Statue Source: PT Angkasa Pura I

YIA is the face of Yogyakarta and even the Nusantara civilization. Hamemayu Hayuningrat has a meaning as a civilization monument that preserves traditional values as well as a space for new civilizations to grow in accordance with the character of the people of Yogyakarta who are strong and flexible, feminine as well as masculine, a combination of the maritime and agrarian spirit. In line with the spirit of the Renaissance and among the tani trade screens, the manifestation of YIA is based on the noble values of Javanese culture that are dynamic in keeping with the times. YIA is a civilization monument that preserves traditional values as well as becomes a space for new and visionary civilizations to grow. The statue that placed at YIA serves as a greeting so that the gesture of this statue figure is as the host welcoming the guests. The choice to present a female figure is intended to accentuate further the symbolization of the motherland in relation to the concept of father-to-earth. Visually, the statue is a figure of the motherland, which is the location where we live and protect life on earth. The figure of a woman depicts fertility, life, activity, and Javanese women 
who remain obedient to Javanese cultural practices, next, in terms of its function, namely as a greeting (welcome monument) of passengers and visitors entering YIA airport.

The figure of the statue is displayed in its entirety and singularly because it wants to bring out the spirit of a friendly and graceful mother. Gesture The statue in this location means welcoming the guests where it looks as if the gesture is stepping and welcoming a new era, with footwork that is like climbing, depicting the spirit of struggle. Describes the adage "where the earth is set, the sky is upheld". Javanese women's noble dress, wearing jarik cloth and kebaya janggan and carrying a scarf as a symbol of protection, flexibility, and authority. The clothing is meaningful to present a Javanese noble, beautiful, and tough mother/woman. Carrying a golden bowl symbolises a means of offering to God as a form of gratitude to him..

\section{3) Gunungan}

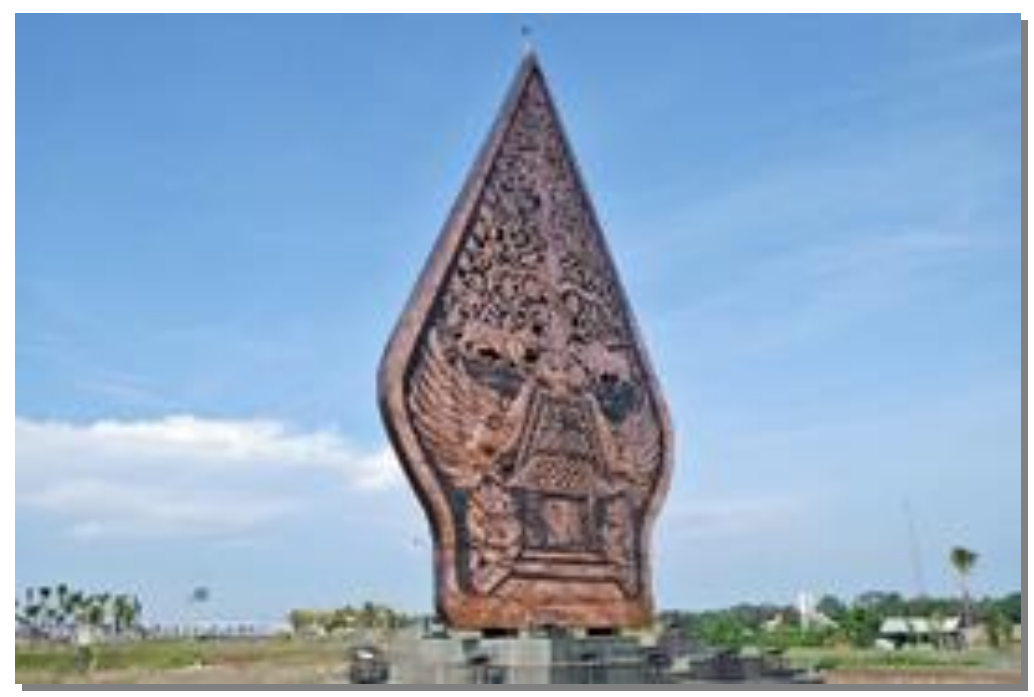

Figure 4. Gunungan Wayang in Yogyakarta International Airport Source: PT Angkasa Pura I

Wayang Gunungan is tapered upwards, which symbolizes human life. Everything in this world will eventually come back "up". The higher the knowledge and the older the man, the closer to the Creator. In addition, each character depicted in Gunungan symbolizes the universe and its contents, starting from humans, animals, plants, and all their accessories.

\section{4) Balekambang}

Balekambang is a building that is above the water. Apart from YIA, Balekambang is also located at Pesanggrahan Ambarukmo, used by Sultan Hamengkubuwana VII for meditation. There are two Balekambang YIA 
buildings, on the west side and the east side. On the west side is an inscription from Batu Merapi, which contains the DIY Governor's concept of a Renaissance Jogja, while on the east side is an inscription from Merapi Rock, which contains the words of the ancestors about the prediction of an airport in the Temon area, Kulon Progo.

\section{5) Hastabrata}

Hastabrata talked about the principles of Javanese leadership. The word "Hastabrata" comes from the Hindu Sanskrit book, Manawa Dharma Sastra, which means that the royal leaders act according to the character of the gods represented into eight natural elements, namely earth, sun, sky, ocean, fire, wind, moon, and stars.
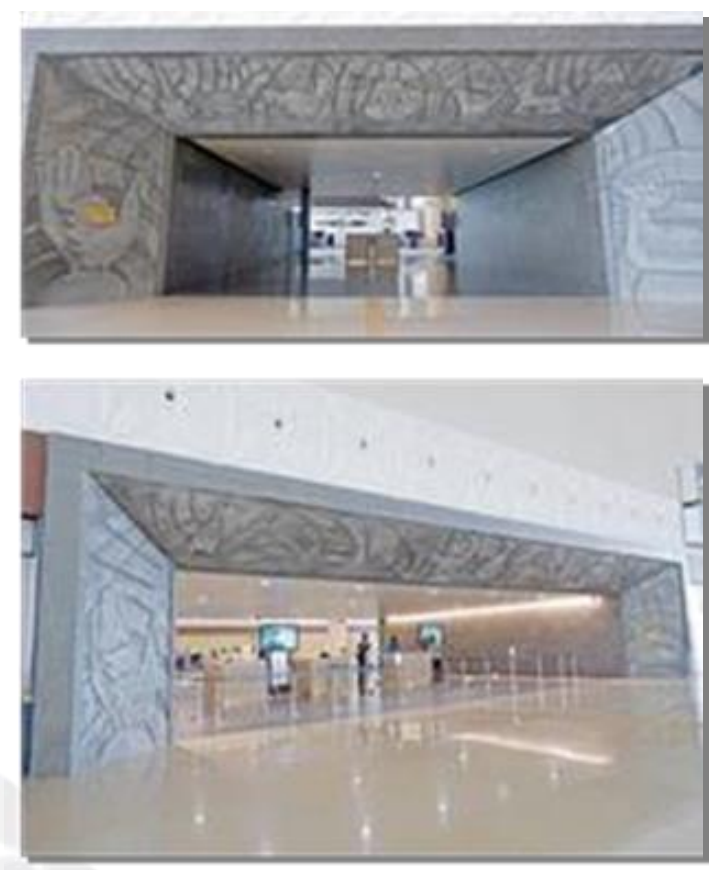

Figure 5. Hastabrata in Yogyakarta International Airport Source: PT Angkasa Pura I

\section{6) Panca Wiwara}

The international and domestic departure gateways are "knowledge doors" of the people's socio-cultural portraits in five villages that were eliminated due to the airport's construction in Kulon Progo, which is immortalized in the form of a story. Panca Wiwara is a form of appreciation for the Kulon Progo people, which is spoken lightly. 


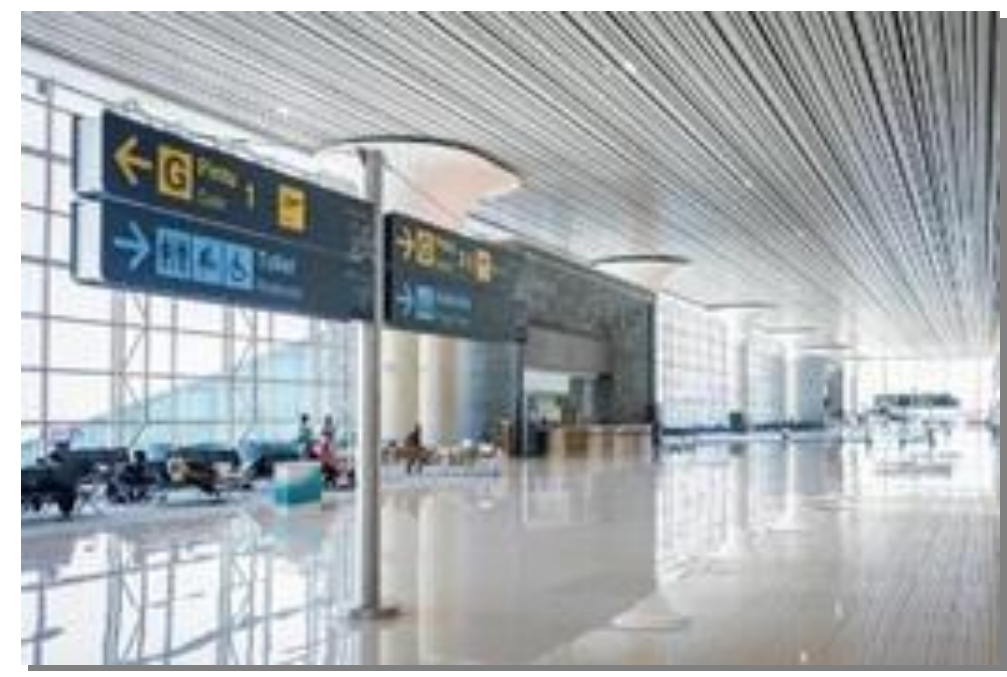

Figure 6. Panca Wiwara in Yogyakarta International Airport Source: PT Angkasa Pura I

\section{Pelican Village}

This relief tells of a discourse that indicates a determination that was initiated from the region regarding Prince Diponegoro's troops' transition to become ordinary people.

\section{Sindutan Village}

The position of Sindutan Village has the main road leading to other areas, such as guarding the direction towards their respective goals and being a link between regions.

\section{Jangkaran Village}

In the past, ship anchors were found in the Jangkaran area. This story has been passed down from generation to generation and is immortalized in domestic departure gates' reliefs.

\section{Glagah Village}

Relief tells about the history and situation in Glagah Village by presenting Punokawan figures as 'pamomong' who are also symbols of the people. Galaga also means flower of sugar cane.

\section{Kebonrejo Village}

Relief tells about the picture of green Royo-Royo gemah ripah Loh jinawi, green plant fertility, and yellow rice fields in rice fields. The embodiment of the local food security centre is reflected in Kebonrejo. In Javanese terms, 'kebon' means garden or field, and 'rejo' means prosperous.

\section{7) Babad Alas}

Taking the story of the beginning of a new civilization in the historical trajectory of Java's land. Babad Alas Mentaok as the birth of Mataram. Babad 
Alas Pabringan early birth of Ngayogyakarta and Babad Alas Nawung Kridha as the beginning of modern Mataram civilization.

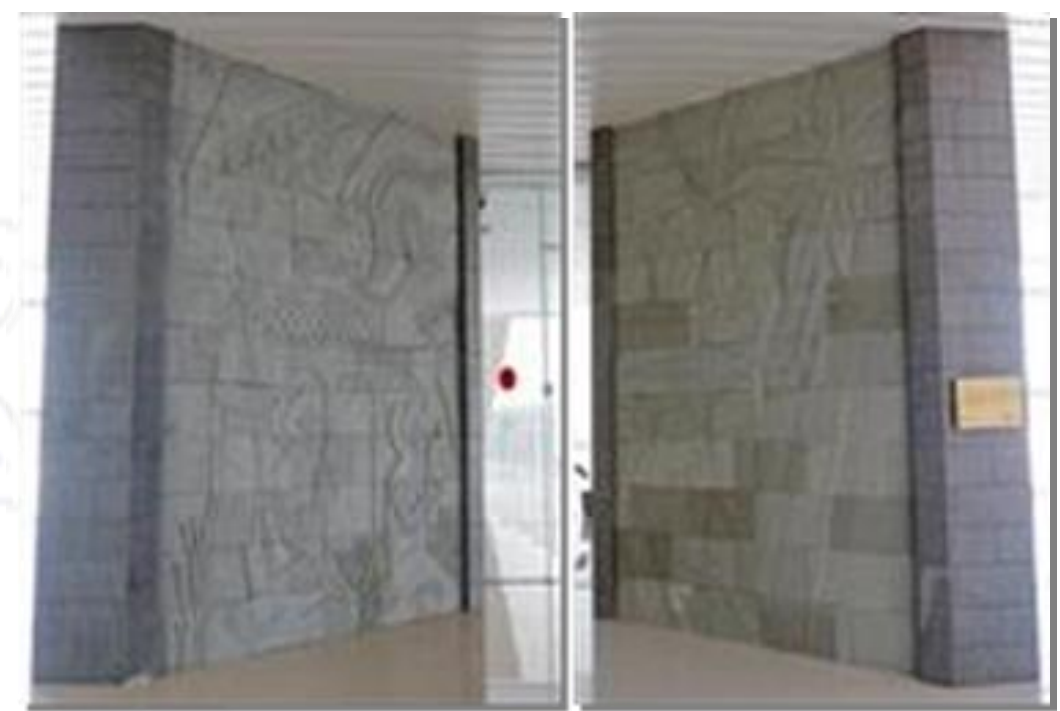

Figure 7. Babad Alas Pabringan in Yogyakarta International Airport Source: PT Angkasa Pura I

\section{Babad Alas Pabringan}

In April 1755 Hamengkubuwana I decided to open the Pabringan Forest as the Ngayogyakarta Hadiningrat Kingdom's capital. Previously, the forest had received a guesthouse named Ngayogya as a resting place when delivering Surakarta's corpse to the Imogiri Cemetery.

\section{Babad Alas Mertani}

The relief narrative of Babad Alas Mertani is almost the same as Babad Alas Wanamarta, but it focuses more on the story of the Pandavas, who then ruled each country whose King they succeeded in conquering so that the kingdom became the kingdom of the Pandavas.

\section{Babad Alas Mentaok I}

Telling Panembahan Senopati built the Islamic Mataram Kingdom. Hutan Mentaok (Javanese: Alas Mentaok) is an area of the Hindu Mataram Kingdom from the 8th century to the 10th century that stretches from the northeast to the southeast of Yogyakarta today.

\section{Babad Alas Mentaok II}

When the Sultan of Panjang was led by Sultan Hadiwijaya (Jaka Tingkir), the Mentaok Forest area was given to Ki Ageng Arrowing as a reward for his success in quelling the Arya Penangsang rebellion (Adipati Kadipaten Jipang Panolan) and later opened into a village by Ki Ageng Penggahan and Ki Juru 
Martani. The village in the Menatok Forest was subsequently named Mataram and had a perdikan or tax free area.

\section{Palihan Nagari}

On Thursday, Pahing, 13 Sura 1682, coinciding with October 7, 1756, Sri Sultan Hamengkubuwono I and his family moved or moved from Pesanggarahan Ambarketawang to enter the new building of the Ngayogyakarta Palace.

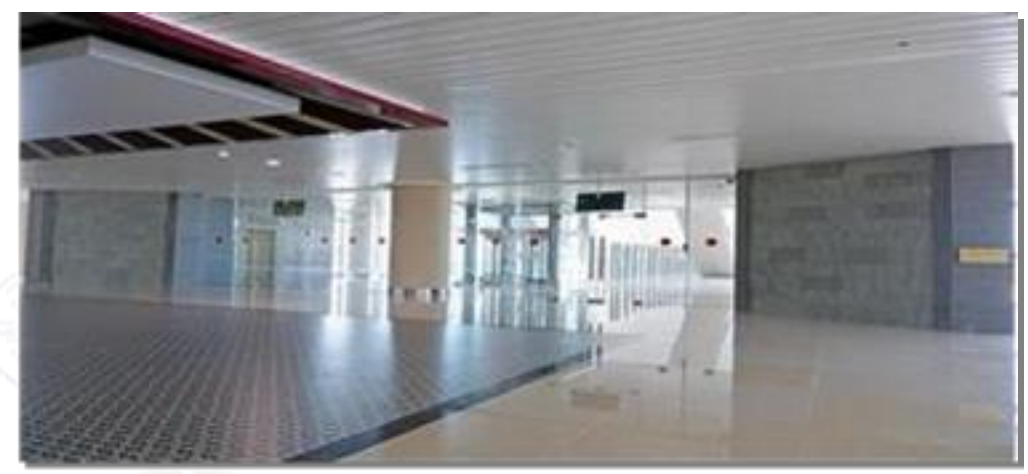

Figure 8. Babad Alas Palihan Nagari I in Yogyakarta International Airport Source: PT Angkasa Pura I

\section{8) Pandawa Babad Alas Wanamarta}

Babad Alas Wanamarta, in the puppet story, is the story of the Pandavas building the State of Amarta. Encouraged by pity for the Pandava children who were still his grandchildren, Prabu Matswapati, the King of the Wirata State, handed over the Mertani Forest (Alas Wanamarta) to the Pandavas. On King Kresna, Raja Negara Dwarawati, Mertani Forest will be built into a state.

\section{9) Bedhaya Kinjeng Wesi Dance}

This sculpture is a symbol of aircraft movements and a visualization of the Bedhaya Kinjeng West dance movement created by a special choreographer to be dedicated to the iconic dance of Yogyakarta International Airport (YIA). This dance means humans are part of the universe (macro cosmos), but there is also a universal work system within themselves (microcosmos) in humans. This shows that Javanese humans are highly civilized, capable of discovering and understanding the universe's interactions. The sculpture is made with sufficient dimensions as a communication space (interface), commercial areas, and waiting areas. 
IJCAS-Vol.8 No.1, June 2021

p-ISSN 2339-191X | e-ISSN 2406-9760
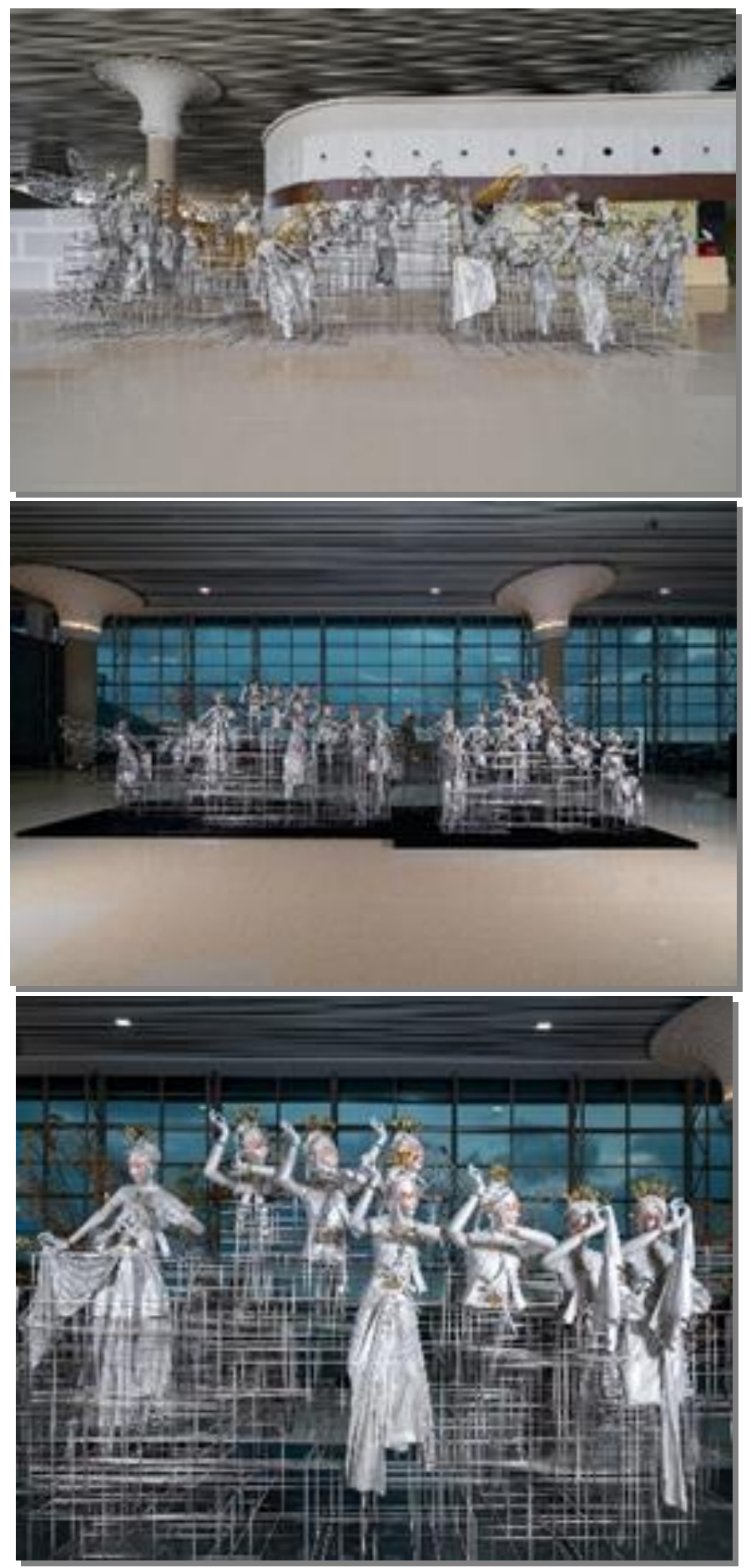

Figure 9. Statue of Tari Bedhaya Kinjeng Wesi in Yogyakarta International Airport Source: PT Angkasa Pura I 
10) Among Bocah

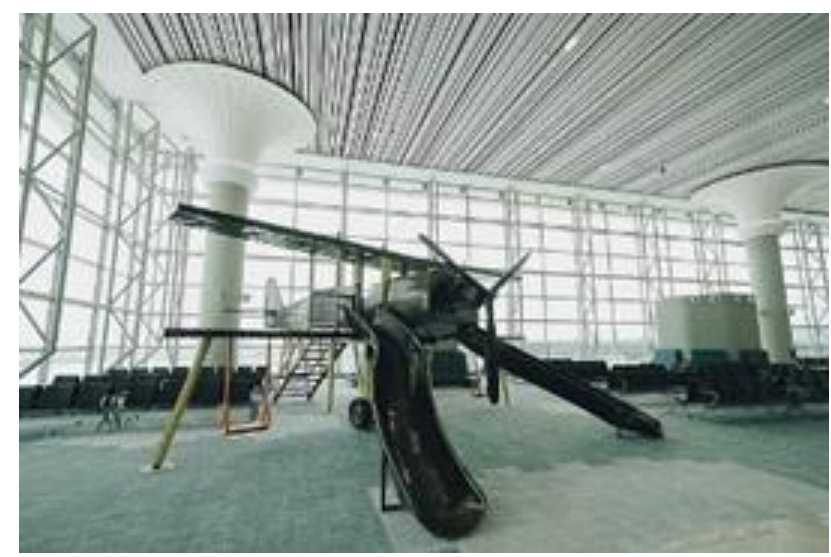

Figure 10. Wahana Among Bocah in Yogyakarta International Airport Source: PT Angkasa Pura I

Among Bocah is a playground for children in the form of a biplane. In the manufacturing process, artists are very concerned about artistic and aesthetic effects so that they are unique and not the same as playing areas elsewhere that seem uniform. This play area is safe, comfortable, and fun for children and a place for education and cultural introduction through traditional games (swings, slides), which are packaged in a modern and artistic form.

\section{1) Panca Desa}
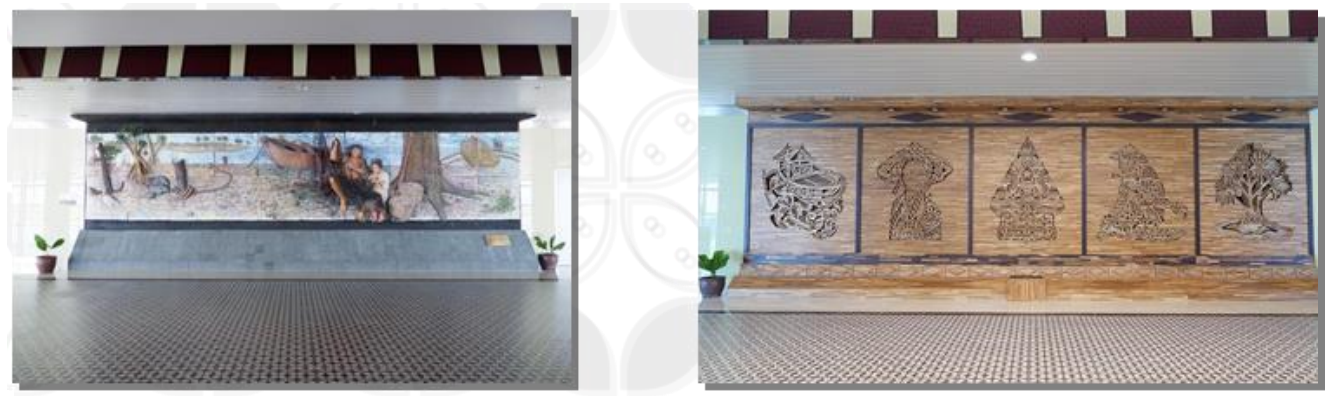

Picture 11. Panca Desa Design in Yogyakarta International Airport Source: PT Angkasa Pura I

The story tells about the romanticism of five villages (Glagah, Sindutan, Jangkaran, Palihan, and Kebonrejo) which were eliminated from the impact of the airport construction as an appreciation for the Kulon Progo people.

\section{2) Among Tani Dagang Layar}

Among Tani Dagang Layar tells of a parade of various village professions, namely fishermen, farmers, and traders, on their way to traditional markets on market days. Javanese market days such as Legi, Pahing, Pon, Wage, and Kliwon 
are still the benchmark for trading systems and calendar systems for people in Java.

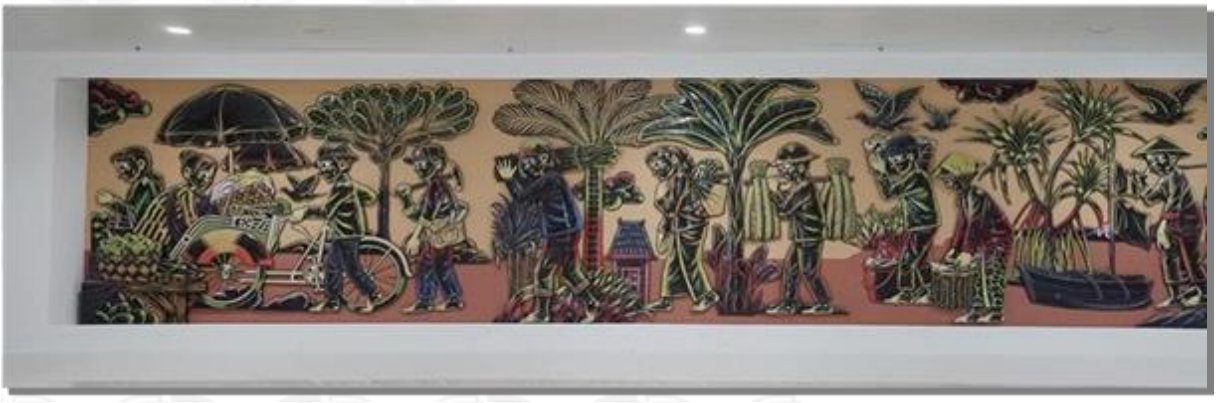

Picture 12. Among Tani Dagang Layar in Yogyakarta International Airport Source: PT Angkasa Pura I

\section{3) Tetanduran}

Tetanduran (Javanese: plant) is a symbol of the local vegetation of Kulon Progo in the form of the mangosteen tree stylization.

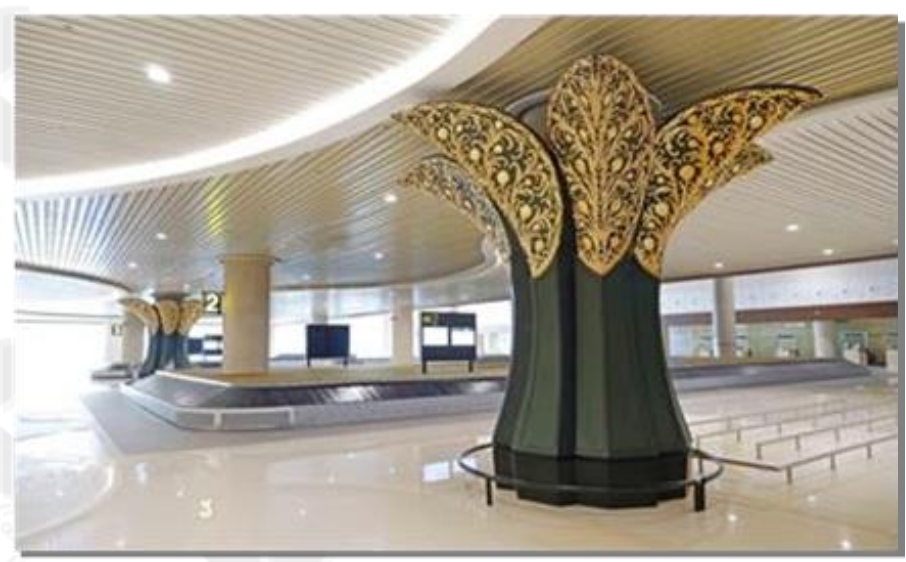

Picture 13. Tetanduran in Yogyakarta International Airport Source: PT Angkasa Pura I

\section{4) Lawang Papat}

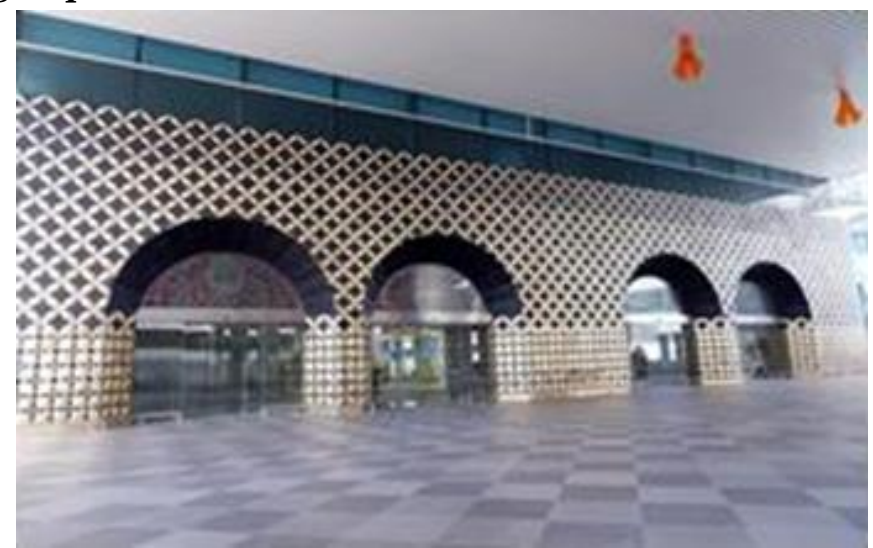

Picture 14. Lawang Papat in Yogyakarta International Airport Source: PT Angkasa Pura I 
Lawang Papat is the Kori Agung or the Main Gate to enter Yogyakarta and is a symbol of the four cardinal directions that rest on one goal with the application of kawung motif texture. Lawang Papat is wrapped in kawung motif, which has a graded shape as a symbol of development and unity to achieve a comfortable life. The four gates are also a symbol of the entrance to Yogyakarta, namely Kulon Progo, Gunung Kidul, Bantul, and Sleman.

\section{5) Tamansari}

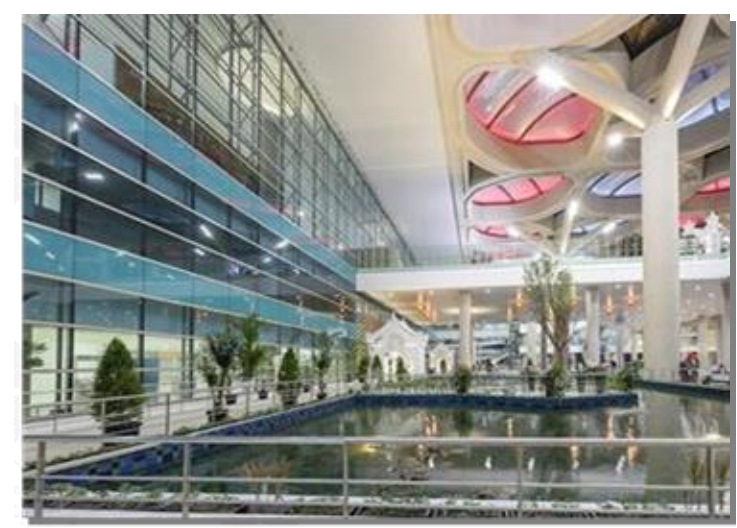

Picture 15. Tamansari in Yogyakarta International Airport Source: PT Angkasa Pura I

Tamansari, which means "beautiful garden", was originally a palace garden or the Yogyakarta Palace garden. Tamansari consists of several buildings, bathing pools, suspension bridges, water canals, artificial lakes, artificial islands, mosques, and underground passages. The park is nicknamed the Water Kasteel (water palace) because of the pools and water elements. Tamansari at YIA is a mini replica that adapts the original Tamansari.

\section{6) Gumuk Pasir}

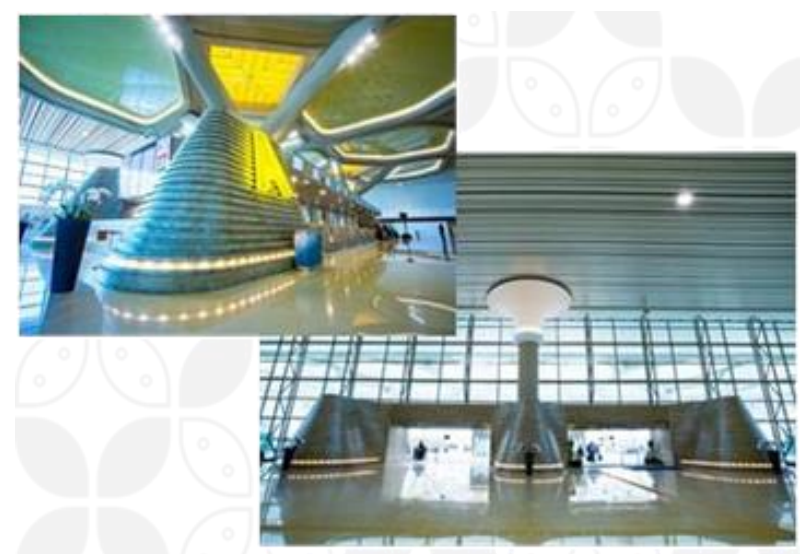

Picture 16. Gumuk Pasir in Yogyakarta International Airport Source: PT Angkasa Pura I 
The "Gumuk Pasir" design in the check-in area depicts dunes' natural phenomenon in Yogyakarta (Parangtritis coast and Parangkusumo beach). In Southeast Asia, dunes are only available in three countries, namely the Philippines (La Paz San Dunes), Vietnam (Mui Ne Sand Dunes), and Indonesia (Gumuk Pasir Yogyakarta).

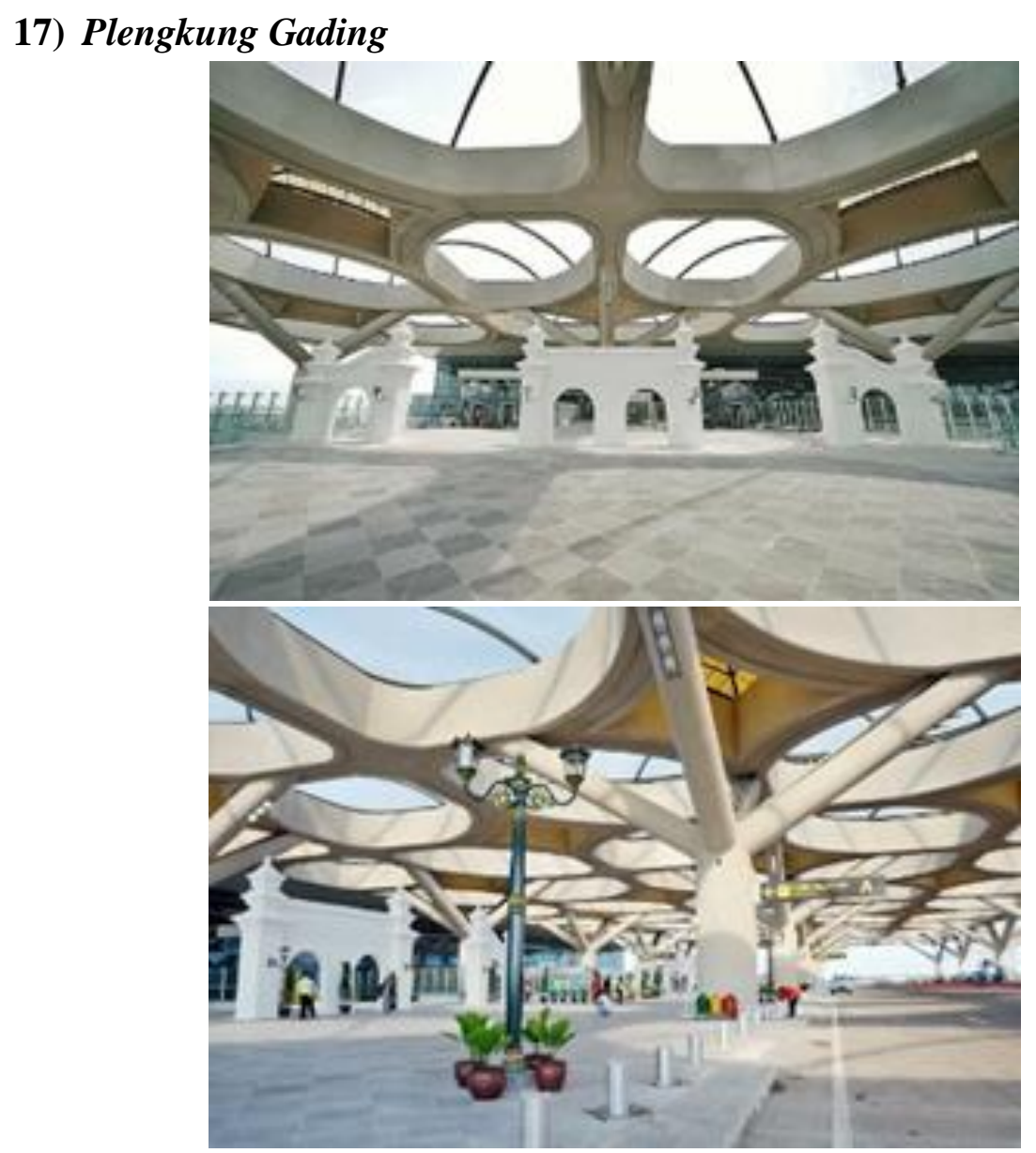

Picture 17. Plengkung Gading in Yogyakarta International Airport Source: PT Angkasa Pura I

\section{B. Fragrance}

The sensation of air freshener at YIA uses a selection of fresh Yogyakarta spices, namely Wedang Uwuh spices, consisting of herbs, bay leaves, lemongrass, ginger, kencur, lime leaves, and cinnamon.

\section{Gamelan and Javanese Songs}

The sensation of passengers' sensory experience at YIA with classical Yogyakarta music strains through the Javanese gamelan repertoire. This sound ambience is also applied to the Binaural Wave in gamelan music. The Binaural 
Wave is adapted to evoke a certain mood for the passengers. For example, Beta Wave increase energy, Alpha Wave induce relaxation.

\section{CONCLUSION}

From those results and discussions, we can perceive that (1) the airport is one of the media, which can show the values of local wisdom of a region or area, and (2) that local wisdom is formed by ideologies contained in society and values of historical culture. In this research, we found three aspects of local wisdom contained in Yogyakarta International Airport. Those three aspects are divided into eighteen branches in the main concepts of the Jogja Renaissance. Jogja Renaissance is a mega project of PT Angkasa Pura I and PT PP, under the authorised of the Ministry of Transportation. In its development, PT Angkasa Pura and PT PP has consulted Jogja Renaissance is planning with Sultan Hamengkubuwono X as Sultan and Governor of Special Region of Yogyakarta (Andika Dannysia, open interview, September 17, 2020).

We see a pool of field in aviation that has not been discussed in the research. We do hope this research can give a new perspective in the art and aviation industry. On the other hand, we have not talked about (1) the art perspective in airports' local wisdom, (2) the cultural effect in adding local wisdom in the airport, and (3) the philosophy of the local wisdom itself. Those aspects run such an exciting role and full of novelty in their context related to interdisciplinary study.

\section{REFERENCES}

Cornock, M. (2018). General Data Protection Regulation (GDPR) and implications for research. In https://doi.org/10.1016/j.maturitas.2018.01.017

Creswell, J. W., \& Plano-Clark, V. L. (2011). Choosing a mixed-methods design. Designing and Conducting Mixed Method Research.

Haryanto, J. T. (2014). Kearifan Lokal Pendukung Kerukunan Beragama pada Komuntias Tengger Malang Jatim. Analisa. https://doi.org/10.18784/analisa.v21i02.15

Istiawati, N. F. (2016). PENDIDIKAN KARAKTER BERBASIS NILAI-NILAI KEARIFAN LOKAL ADAT AMMATOA DALAM MENUMBUHKAN KARAKTER KONSERVASI. CENDEKIA: Journal of Education and Teaching. https://doi.org/10.30957/cendekia.v10i1.78

Palinkas, L. A., Horwitz, S. M., Green, C. A., Wisdom, J. P., Duan, N., \& Hoagwood, K. (2015). Purposeful Sampling for Qualitative Data Collection and Analysis in Mixed Method Implementation Research. Administration and Policy in Mental Health and Mental Health Services 
Research. https://doi.org/10.1007/s10488-013-0528-y

Steelyana, E. (2012). Batik, A Beautiful Cultural Heritage that Preserves Culture and Supporteconomic Development in Indonesia. Binus Business Review. https://doi.org/10.21512/bbr.v3i1.1288

Sugiyono. (2015). Metode Penelitian. Bandung: Alfabeta.

Sutarso, J., \& Murtiyoso, B. (2008). Wayang Sebagai Sumber dan Materi Pembelajaran Pendidikan Budi Pekerti Berbasis Budaya Lokal. Jurnal Penelitian Humaniora.

Suter, W. (2014). Qualitative Data, Analysis, and Design. In Introduction to Educational Research: A Critical Thinking Approach. https://doi.org/10.4135/9781483384443.n12

Timbul, S. (2016). Bela Negara Dan Kebijakan Pertahanan. Majalah WIRA.

Williamson, K., Given, L. M., \& Scifleet, P. (2018). Qualitative data analysis. In Research Methods: Information, Systems, and Contexts: Second Edition. https://doi.org/10.1016/B978-0-08-102220-7.00019-4 